\title{
Structural Equation Modelling Approach to Determine the Mother and Child Health Care in Madurai District, Tamil Nadu
}

\author{
S. Eswari, V. Saravanabavan, D. Balaji
}

Department of Geography, Madurai Kamaraj University, Madurai, Tamil Nadu, India

Article Info

Volume 8, Issue 2

Page Number : 335-344

\section{Publication Issue}

March-April-2021

\section{Article History}

Accepted : 01 April 2021

Published : 08 April 2021

\section{ABSTRACT}

The present study attempt to describe the determinants of mother and child healthcare in Madurai District. To assess whether the exogenous constructs are highly correlated to each other and to identify the type of mediation exists in a model. The information was collected from the mother(s) lives in 13 blocks of Madurai district. The data collected for the year 2017-2018 and each block, 50 mothers were selected (13X50) and totally 650 samples were collected by random sampling method and they are the respondents of this study. The questions are related to their socio-economic status, attitude towards antenatal healthcare providers, healthcare utilization, child care, health problems, and psychological conditions. This information was transformed and confirmatory factor analysis was performed using SPSS software. Further, for the interpretation and findings, factor analysis, discriminant validity, path analysis with structural equation model (SEM) (direct relationship) and bootstrap approach (indirect relationship) was carried out by using AMOS software to validate the type of mediation found in this study. Hence, this study analyses the relationship of selected variables with mother and child care of women in the study area.

Keywords : SEM, AMOS, SPSS, Confirmatory Factor Analysis, Bootstrap Approach

\section{INTRODUCTION}

The healthy mother delivers a healthy baby and they are the future of a nation. Therefore, a nation should have healthy children to make a healthy nation. At this juncture, our country is making wonderful policies, planning and implementation through various healthcare programmes for the care of mother and child health. Structural equation modelling is a mediation model and to conduct a formal test on mediation effects. The effect of the independent variable on the dependent variable is triggered by the mediator variable. Such an effect was termed as an indirect effect (Shrout \& Bolger, 2002). Aiken, West, Woodward, Reno, and Reynolds (1994) examined the mediating effects of four perceptions perceived susceptibility to breast cancer, perceived severity of consequences of breast cancer. Constantine (2007) 
examined the mediating roles of general and multicultural counselling competence and clientcounsellor therapeutic alliance in the relationship between subtle racist denigration and satisfaction with counselling.

The testing of multiple mediation hypotheses is somewhat arcane, relative to those for simple mediation and only a few authors (Bollen, 1987, 1989; Brown, 1997; Cheung, 2007; MacKinnon, 2000). Antenatal care is the care given to pregnant women so that they have a safe pregnancy and a healthy baby (Abosse Z, Woldie M, Ololo S (2010).). Antenatal care visits to identify the complications like preterm delivery and manage these complications in a timely manner (Finlayson K, Downe S. (2013). The first visit is important because that is when a woman receives a complete assessment of gestational age and the risk factors (WHO Global Health Observatory, 2011).

\section{Study Area}

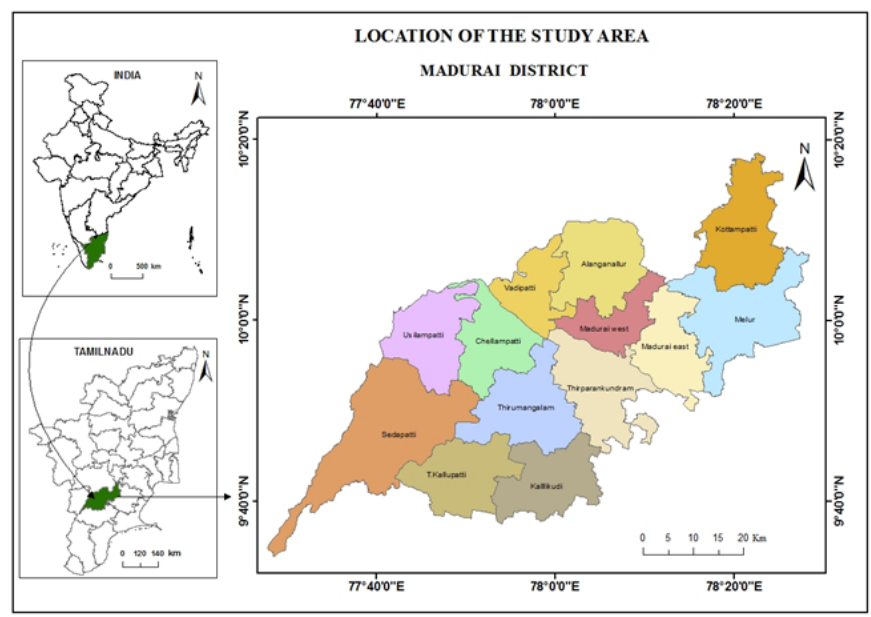

Fig. 1 Location of the Study Area

Madurai District is situated in the south of Tamil Nadu State with an area of $143.08 \mathrm{~km} 2$. According to 2017-2018, Statistical Handbook of Madurai District the density of population is 812 per sq.km. It is the ninth-largest populated district in Tamil Nadu. In the year 1984, Madurai District was bifurcated into two administrative division Madurai and Dindigul. Again in the year 1997, it was bifurcated as Madurai and
Theni Districts. Madurai is also known as Temple City. World Famous Sri Meenakshi Sundareshwarar Temple is in Madurai. Madurai District is influenced by various religions such as Christianity, Hinduism, Islam, Sikh, Buddhist and Jain which cause diverse entity. In the year 2011, Madurai Corporation was expanded from 72 wards to 100 wards and dividing into four regions (Fig.1). Madurai is known for its hot climate. The average annual rainfall for 2018 was $85.76 \mathrm{~cm}$.

\section{Database and Methodology}

This present study is based on a questionnaire survey. The information was collected from the mother(s) lives in 13 blocks of Madurai district. The data collected for the year 2017-2018 and each block, 50 mothers were selected (13X50) and totally 650 samples were collected by random sampling method and they are the respondents of this study. The questions are related to their socio-economic status, attitude towards antenatal healthcare providers, healthcare utilization, child care, health problems, and psychological conditions. This information was transformed and confirmatory factor analysis was performed using SPSS software. Further, for the interpretation and findings, factor analysis, discriminant validity, path analysis with structural equation model (direct relationship) and bootstrap approach (indirect relationship) was carried out by using AMOS software to validate the type of mediation found in this study. The three important techniques used in the present study SPSS, AMOS and GIS. The maps are prepared using GIS Software. ArcGIS is one of the important GIS software, which is used to prepare the maps. Hence, this study analyses the relationship of selected variables with mother and child care of women in the study area. 


\section{Results and Discussion}

Factor I : Experience of Health Problems during PreNatal Period

Healthcare during prenatal period is more vital for mother, child and safe delivery. Thus, the first - factor healthcare during the prenatal period has emerged as a most important factor with the total variance of 19.033 per cent with an eigenvalue of 3.807 per cent (Table 1). Six out of twenty variables are positively loaded on this factor specifically, have you experienced any problems during the prenatal period (0.886), have you experienced any problem at the place of treatment during the prenatal period (0.847), did you get treated for any problems during the prenatal period $(0.840)$, why are you not visiting any gynaecologist for treatment (0.707), did you take any special care during menstruation (0.687), and have you experienced any respiratory disease/asthma (0.618). As a result, the data set confirmed that the childbearing women in the study area are having experience of health problems during the prenatal period. The spatial pattern of experience of health problems during prenatal period in Madurai District of mean factor score is (Fig. 2) revealed that the high positive to low positive score observed in the blocks of T. Kallupatti (0.378), Madurai West (0.688), Sedapatti (0.475), Usilampatti (0.378), Vadipatti (0.378), Alanganalur (0.475), and Kottampatti (0.378) this clearly indicates that the health-seeking behaviours (post-natal healthcare) are highly satisfied in these blocks. Similarly, the low to high negative mean factor scores registered in the blocks of Chellampatti (-0.378), Kallikudi (-0.483), Thiruparankundram (-0.483), Melur (-0.391), Thirumangalam (-0.667), and Madurai East (-0.667). This is undoubtedly demonstrating that post-natal healthcare-seeking behaviours are dissatisfied for the above-mentioned blocks.
Table 1. Experience of Health Problems during PreNatal Period

\begin{tabular}{|c|c|c|c|}
\hline $\begin{array}{l}\text { Variable } \\
\text { No. }\end{array}$ & Variable Name & $\begin{array}{l}\text { Factor } \\
\text { Loading }\end{array}$ & Communalities \\
\hline Hc1 & $\begin{array}{l}\text { Have you } \\
\text { experienced } \\
\text { any problems } \\
\text { during prenatal } \\
\text { period }\end{array}$ & 0.886 & 0.830 \\
\hline Hc2 & $\begin{array}{l}\text { Have you } \\
\text { experienced } \\
\text { any problem at } \\
\text { the place of } \\
\text { treatment } \\
\text { during prenatal } \\
\text { period }\end{array}$ & 0.847 & 0.775 \\
\hline Hc3 & $\begin{array}{l}\text { Did you get } \\
\text { treated for any } \\
\text { problems } \\
\text { during prenatal } \\
\text { period }\end{array}$ & 0.840 & 0.775 \\
\hline Hc4 & $\begin{array}{l}\text { Why are you } \\
\text { not visiting an } \\
\text { gynecologist } \\
\text { for treatment }\end{array}$ & 0.707 & 0.594 \\
\hline Hc5 & $\begin{array}{l}\text { Did you take } \\
\text { any special care } \\
\text { during } \\
\text { menstruation }\end{array}$ & 0.687 & 0.604 \\
\hline Hpp1 & $\begin{array}{l}\text { Have you } \\
\text { experienced } \\
\text { any respiratory } \\
\text { Disease/Asthma }\end{array}$ & 0.618 & 0.536 \\
\hline \multicolumn{2}{|c|}{ Eigen value: 3.807} & \multicolumn{2}{|c|}{ Total Variance: 19.033} \\
\hline \multicolumn{4}{|c|}{$\begin{array}{l}\text { Extraction Method: Principal Component Analysis. } \\
\text { Rotation Method: Varimax with Kaiser Normalization. } \\
\text { Rotation converged in } 6 \text { iterations. }\end{array}$} \\
\hline
\end{tabular}




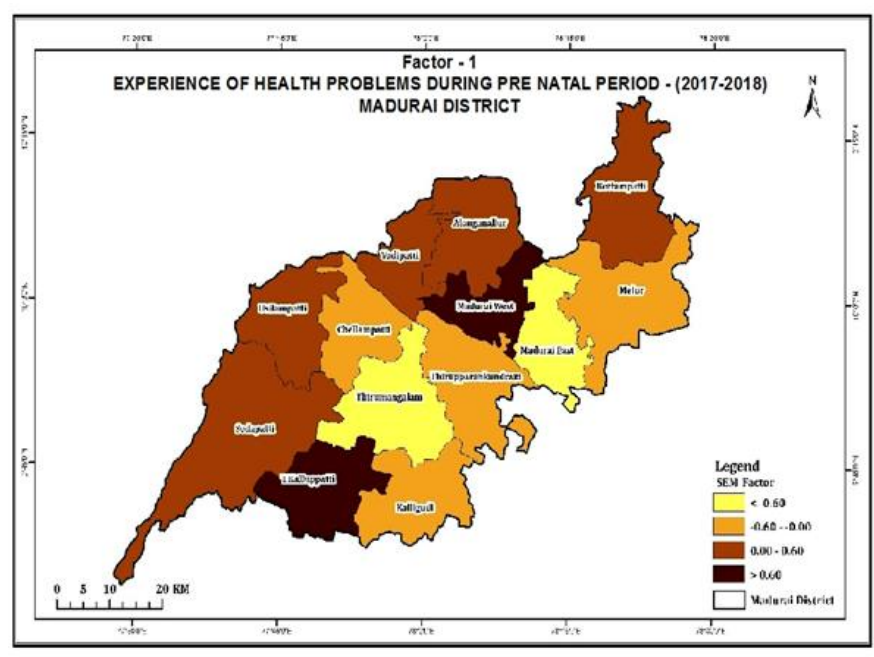

Fig. 2. Experience of Health Problems during PreNatal Period - (2017-2018)

\section{Factor II : Health Problem during Pregnancy}

All pregnant women are facing pregnancy complications, continuous monitoring of mother health condition and child growth is mandatory to reduce such problems. Therefore, the second most important factor health problem during pregnancy has emerged with a total variance of 17.918 per cent with an eigenvalue of 3.584 per cent (Table 2). According to the data set four and one out of twenty variables positively and negatively loaded on this factor respectively. Specifically, these variables are, do you get any kidney disease or urinary tract infections (0.881), do you have hepatitis liver disease/jaundice (0.853), did you get tuberculosis (0.844) and have you experienced abnormal Pap smear (0.771). However, the variable does you feel comfortable with sexual and reproductive health services in your area $(-0.731)$ is negatively loaded on this factor, which reveals that the respondents are not satisfied with health service providers of this region. Therefore, maternal women in the study region are facing one or more pregnancy problems.
Table 2. Health Problem during Pregnancy

\begin{tabular}{|l|l|l|l|}
\hline $\begin{array}{l}\text { Variable } \\
\text { No. }\end{array}$ & Variable Name & $\begin{array}{l}\text { Factor } \\
\text { Loading }\end{array}$ & Communalities \\
\hline Hpp2 & $\begin{array}{l}\text { Did you get } \\
\text { any kidney } \\
\text { disease or } \\
\text { urinary tract } \\
\text { infections }\end{array}$ & 0.881 & 0.779 \\
\hline Hpp3 & $\begin{array}{l}\text { Do you have } \\
\text { hepatitis liver } \\
\text { disease } \\
\text { /Jaundice }\end{array}$ & 0.853 & 0.735 \\
\hline Hpp4 & $\begin{array}{l}\text { Did you get } \\
\text { tuberculosis }\end{array}$ & 0.844 & 0.717 \\
\hline Hpp5 & $\begin{array}{l}\text { Have you } \\
\text { experienced } \\
\text { abnormal Pap } \\
\text { smear }\end{array}$ & 0.771 & 0.622 \\
\hline Esy1 & $\begin{array}{l}\text { Do you feel } \\
\text { comfortable } \\
\text { with sexual } \\
\text { and } \\
\text { reproductive } \\
\text { health services } \\
\text { in your area }\end{array}$ & -0.731 & 0.555 \\
\hline value: 3.584 & Total Variance: 17.918 \\
\hline
\end{tabular}

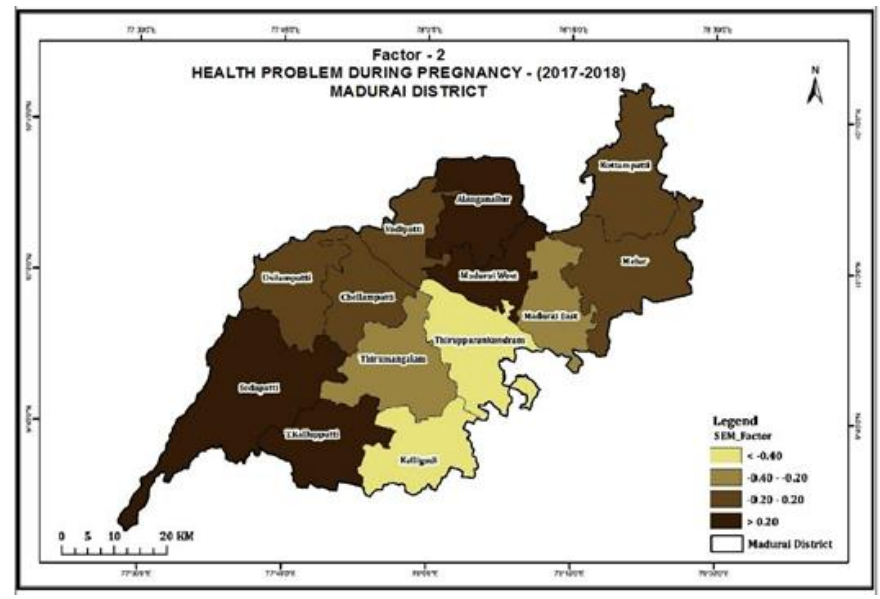

Fig. 3 Health Problem during Pregnancy - (2017-2018) 
The fig. 3 illustrating the spatial pattern of mean factor score of Health problem during Pregnancy of Madurai District. The very high to high positive score are noticed in the blocks of Sedapatti (0.195), T. Kallupatti (0.177), Alanganalur (0.195), Madurai West (0.177), Usilampatti (0.127), Chellampatti (0.125), Vadipatti (0.127), Melur (0.125), and Kottampatti (0.127). The very low mean factor score perceived in the blocks of Thirumangalam $(-0.157)$, Madurai east (-0.157), Thiruparankundram $(-0.467)$, and $(-0.467)$. This is evidently proved that the mean positive and negative factor scores exhibit satisfied and dissatisfied health problem during pregnancy in the blocks of Madurai district respectively.

\section{Factor III : Child Care}

The child is an important asset for a parent and nation. Healthy child's nation is a wealthy nation. So, every parents and nation are looking healthy child. Thus, the third vital factor childbirth has emerged with a total variance of 14.755 per cent with an eigenvalue of 2.955 per cent (Table 3). Four out of twenty variables are positively loaded on this factor particularly what is the time duration of breastfeeding your children (0.865), what is the weight of the baby during delivery (0.853), have you seen any abnormalities during birth (0.816) and what are the types of labour and its complications (0.811). As a result, the reproductive mothers in this region are taking utmost care for their child. The areal differentiation of very high to high mean positive factor score for Childcare Madurai District established in the blocks (Fig. 4) of Chellampatti (0.111), Kallikudi (0.115), Thiruparankundram (0.115), Melur (0.111), Usilampatti (0.015), Vadipatti (0.015), and Kottampatti (0.015). The very low negative mean factor score recognized in the blocks of Thirumangalam (-0.060), Madurai East (-0.060), Sedapatti (-0.101), T. Kallupatti (-0.081), Alanganalur $(-0.101)$, and Madurai West (-0.081) for the Childcare in Madurai District.
Table 3. Child Care

\begin{tabular}{|c|c|c|c|}
\hline $\begin{array}{l}\text { Variable } \\
\text { No. }\end{array}$ & $\begin{array}{l}\text { Variable } \\
\text { Name }\end{array}$ & $\begin{array}{l}\text { Factor } \\
\text { Loading }\end{array}$ & Communalities \\
\hline $\mathrm{Cb} 1$ & $\begin{array}{l}\text { What is the } \\
\text { time duration } \\
\text { of } \\
\text { breastfeeding } \\
\text { your children }\end{array}$ & .865 & 0.752 \\
\hline $\mathrm{Cb} 2$ & $\begin{array}{l}\text { What is the } \\
\text { weight of the } \\
\text { baby during } \\
\text { delivery }\end{array}$ & .853 & 0.748 \\
\hline Cb3 & $\begin{array}{l}\text { Have you } \\
\text { seen any } \\
\text { abnormalities } \\
\text { during birth }\end{array}$ & .816 & 0.715 \\
\hline Gp1 & $\begin{array}{l}\text { What are the } \\
\text { types of } \\
\text { labour and its } \\
\text { complications }\end{array}$ & .811 & 0.694 \\
\hline Eigen $\mathbf{v}$ & 2.955 & \multicolumn{2}{|c|}{ Total Variance: 14.755} \\
\hline
\end{tabular}

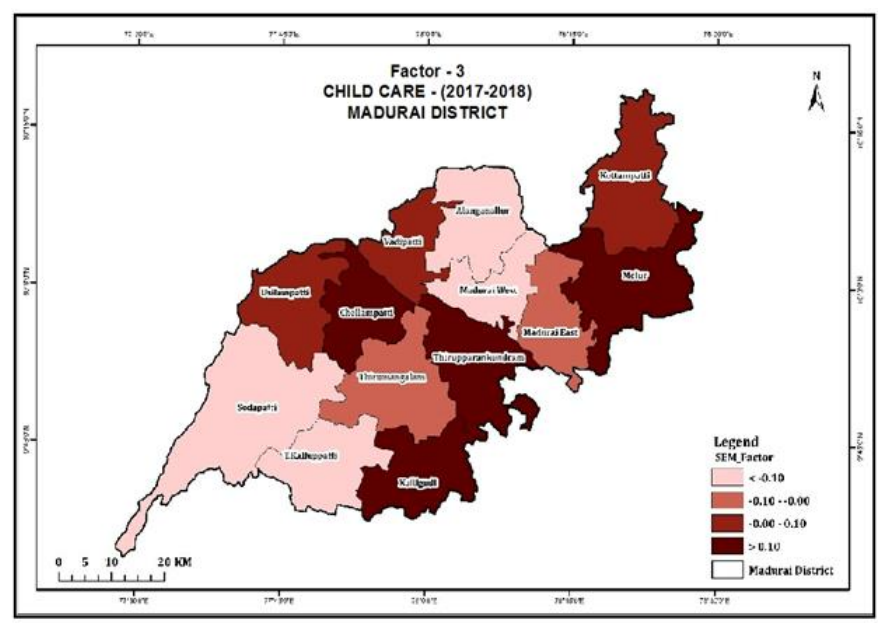

Fig. 4 Child Care - (2017 - 2018)

\section{Factor IV: Infant Death}

The occurrence of infant death is decreasing in India and its states particularly in Tamil Nadu because of the implementation of healthcare plan wisely. Thus, the fourth vital factor childbirth has emerged with a total variance of 9.365 per cent with an eigenvalue of 
1.873 per cent (Table 4). Two out of twenty variables are positively loaded on this factor chiefly what is the number of infant deaths (0.770) and what is the health condition of educated pregnant women (0.675). In contrast, one variable was negatively loaded on this factor namely am I satisfied in my health condition (0.671). Hence, the number of infant deaths related to the health condition of educated women and these variables are negatively loaded with the satisfaction level of mothers' health condition in this study area.

Table 4. Infant Death

\begin{tabular}{|l|l|l|l|}
\hline $\begin{array}{l}\text { Variable } \\
\text { No. }\end{array}$ & Variable Name & $\begin{array}{l}\text { Factor } \\
\text { Loading }\end{array}$ & Communalities \\
\hline Id1 & $\begin{array}{l}\text { What is the } \\
\text { number of } \\
\text { infant deaths }\end{array}$ & .770 & 0.731 \\
\hline Sec1 & $\begin{array}{l}\text { What is the } \\
\text { heath } \\
\text { condition of } \\
\text { educated } \\
\text { pregnant } \\
\text { women }\end{array}$ & .675 & 0.527 \\
\hline Psy2 & $\begin{array}{l}\text { Am I satisfied } \\
\text { in my health } \\
\text { condition }\end{array}$ & -.671 & 0.630 \\
\hline $\begin{array}{l}\text { Eigen value: } \\
1.873\end{array}$ & \begin{tabular}{l} 
Total Variance: 9.365 \\
\hline
\end{tabular}
\end{tabular}

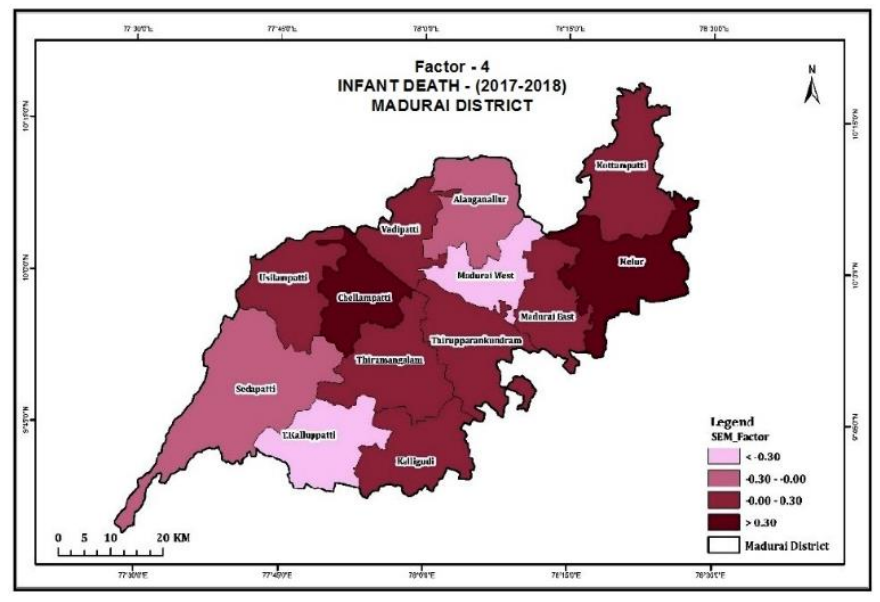

Fig. 5 Infant Death - (2017 - 2018)
The very high to high mean factor score for infant death in Madurai District (Fig. 5) observed in the blocks Chellampatti (0.327), Melur (0.327), Usilampatti (0.083), Thirumangalam (0.103), Kallikudi (0.092), Thiruparankundram (0.092), Vadipatti (0.083), Madurai East (0.103), and Kottampatti (0.083). In contrast, the very low to low mean negative factor score for infant death found in the blocks of Sedapatti (-0.098), Alanganalur (-0.098), T. Kallupatti (-0.507), and Madurai West (-0.507).

\section{Factor V: Utilization of Healthcare}

The mother and child health condition mainly depends on the utilization of available healthcare centres in a region. Accordingly, this study area woman revealed that I received prenatal care during pregnancy (0.909) and I took medical check-ups during pregnancy $(0.881)$. Thus, the fifth important factor utilization of healthcare has emerged with a total variance of 9.114 per cent with an eigenvalue of 1.823 per cent (Table 5). Therefore, these study area pregnant women receive proper healthcare services from the healthcare providers in time.

Table 5. Healthcare Utilization

\begin{tabular}{|l|l|l|l|}
\hline $\begin{array}{l}\text { Variable } \\
\text { No. }\end{array}$ & $\begin{array}{l}\text { Variable } \\
\text { Name }\end{array}$ & $\begin{array}{l}\text { Factor } \\
\text { Loading }\end{array}$ & Communalities \\
\hline Hu1 & $\begin{array}{l}\text { I received } \\
\text { prenatal } \\
\text { care } \\
\text { during } \\
\text { pregnancy }\end{array}$ & .909 & 0.845 \\
\hline Hu4 & $\begin{array}{l}\text { I took } \\
\text { medical } \\
\text { check-ups } \\
\text { during } \\
\text { pregnancy }\end{array}$ & .881 & 0.876 \\
\hline \multicolumn{2}{|l|}{ Eigen value: 1.823 } & \multicolumn{2}{|l|}{ Total Variance: 9.114 } \\
\hline
\end{tabular}




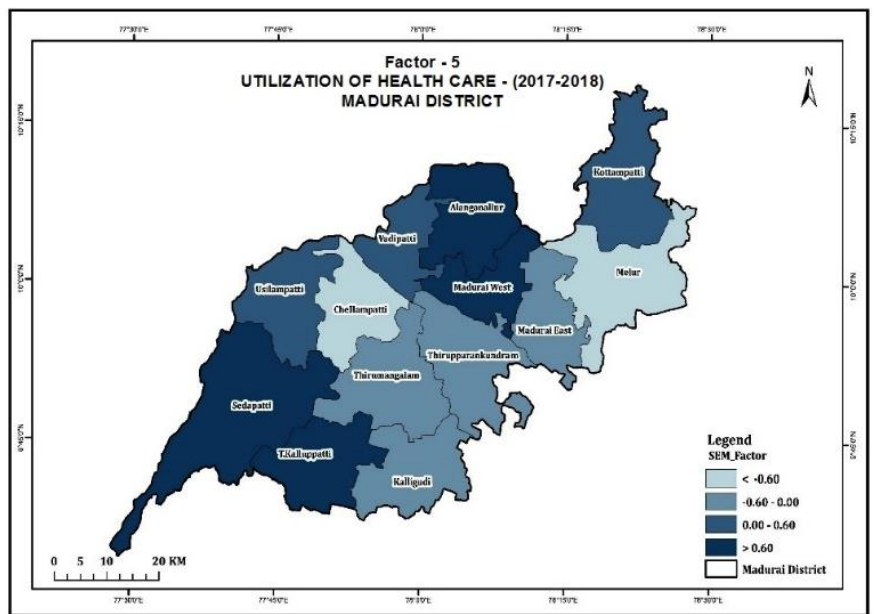

Fig. 6. Utilization of Healthcare - (2017-2018)

The Spatial pattern of very high to high mean factor score of the utilization of health care in Madurai District (Fig. 6) in the blocks of Sedapatti (0.739), T. Kallupatti (0.604), Alanganalur (0.739), Madurai West (0.604), Usilampatti (0.075), Vadipatti (0.075), and Kottampatti (0.075). Likewise, the very low to low negative mean factor score observed the blocks of Thirumangalam (-0.508), Kallikudi (-0.217), Thirumangalam (-0.217), Madurai East $(-0.508)$, Chellampatti (-0.693), and Melur (-0.693) in Madurai district.

\section{Regression Weights: Unstandardized and Standardized co-efficient}

The SPSS-AMOS data set outcome provides seven regression weights, unstandardized and standardized factor model (Fig. 7 and 8) structures for every path and its significance. Table 6 is representing the unstandardized coefficients and associated experiment statistics. The infant death goes up by lunit and child care goes down by 0.070 units. It has a standard error of about 0.075 . Specifically, dividing the regression weight estimate by the estimate of its standard error gives $z=-0.070 / .075=-0.931$. The regression weight for infant death in the prediction of child care is not significant because the $\mathrm{p}$ level is greater than 0.05 . Therefore, the assumption $\left(\mathrm{H}_{1}\right)$ infant death was not having significant impact on child care in this study area. The child care increase by 1 unit and health problem during pregnancy increases by 0.017 units. The standard error is 0.006 . Separating the regression weight estimate by the estimate of its standard error gives $z=0.017 / 0.006=2.637$. Hence, the regression weight for child care in the prediction of health problem during pregnancy is significant $(\mathrm{p}=0.008)$ at the 0.001 level (two-tailed). As a result, the hypothesis $\left(\mathrm{H}_{2}\right)$ child care has significant impact on health problem of women during pregnancy in this district.

The variable health problem during pregnancy ascends by 1 unit and experience of health problems during pre-natal period rises by 0.738 units. The standard error is about 0.256 . Therefore, dividing the regression weight estimate by the estimate of its standard error gives $z=.738 / .256=2.876$. Consequently, the regression weight for health problem during pregnancy in the prediction of experience of health problems during pre-natal period is significant at the 0.001 level (two-tailed). Then, the assumption $\left(\mathrm{H}_{4}\right)$ health problem during pregnancy has significant effect on experience of women's health problems during pre-natal period.

The variable infant death increases by 1 unit and the health problem during pregnancy decreases by 0.042 . It has a standard error of about 0.012. Dividing the regression weight estimate by the estimate of its standard error gives $z=-0.042 / 0.012=-3.584$. The regression weight for infant death in the prediction of health problem during pregnancy is significant ( $\mathrm{p}=0.001)$ at the 0.001 level (two-tailed). Hence, $\left(\mathrm{H}_{3}\right)$ the infant death has significant impact on health problem of women during pregnancy in this study region.

When the infant death goes up by 1 unit and experience of health problems during pre-natal period goes up by 0.328 units and it has a standard error of about 0.075 . Further, separating the regression weight 
estimate by the estimate of its standard error gives $Z$ $=.328 / .075=4.366$. Therefore, the regression weight for infant death in the prediction of experience of health problems during pre-natal period is significant at the 0.001 level (two-tailed). As a result, $\left(\mathrm{H}_{5}\right)$ the infant death has significant effect on experience of health problems during pre-natal period in this study area.

The variable experience of health problems during pre-natal period increases by 1 unit and utilization of healthcare decreases by 0.097 . It has a standard error of about 0.016. Dividing the regression weight estimate by the estimate of its standard error gives $z=$ $-.097 / .016=-6.019$. The regression weight for experience of health problems during pre-natal period in the prediction of utilization of healthcare is significant at the 0.001 level (two-tailed). Therefore,
(H6) the experience of health problems during prenatal period has significant effect on utilization of healthcare in the study area.

The attribute health problem during pregnancy rise up by 1 unit and utilization of healthcare goes down by 0.013 units and it has a standard error of about 0.102. Hence, separating the regression weight estimate by the estimate of its standard error gives $z=$ $-.013 / .102=-.130$. Therefore, the regression weight for health problem during pregnancy in the prediction of utilization of healthcare is not significant $(\mathrm{p}=0.897)$ at the 0.001 level (two-tailed). Consequently, $\left(\mathrm{H}_{7}\right)$ the health problem during pregnancy was not having significant effect on utilization of healthcare.

Table 6. Regression Weights: Unstandardized and Standardized co-efficient

\begin{tabular}{|c|c|c|c|c|c|c|c|c|c|}
\hline $\begin{array}{l}\dot{2} \\
\dot{n}\end{array}$ & 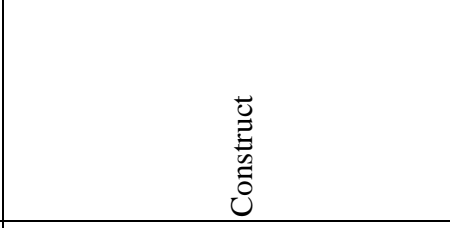 & 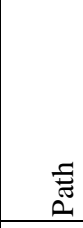 & 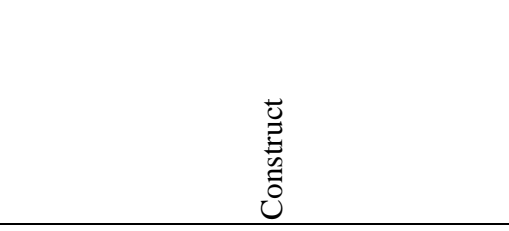 & 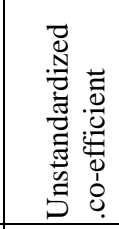 & $\begin{array}{l}\dot{I} \\
\dot{s}\end{array}$ & 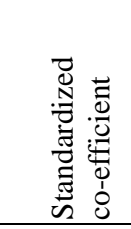 & نُّ & $a$ & $\begin{array}{l}\bar{\Xi} \\
\text { ב్ } \\
\end{array}$ \\
\hline 1 & Child Care & $<--$ & Infant Death & -0.070 & 0.075 & -0.038 & $-\overline{0}-931$ & 0.352 & $\begin{array}{l}\text { Not } \\
\text { Significant }\end{array}$ \\
\hline 2 & Health Problem during Pregnancy & $<--$ & Child Care & 0.017 & 0.006 & 0.106 & 2.637 & $\begin{array}{l}0.008^{*} \\
*\end{array}$ & Significant \\
\hline 3 & Health Problem during Pregnancy & $<--$ & Infant Death & -0.042 & 0.012 & -0.144 & $\begin{array}{l} \\
3.584\end{array}$ & $\begin{array}{l}0.001 * \\
*\end{array}$ & Significant \\
\hline 4 & $\begin{array}{l}\text { Experience of Health Problems } \\
\text { during Pre-Natal Period }\end{array}$ & $<--$ & Health Problem during Pregnancy & 0.738 & 0.256 & 0.116 & 2.876 & $\begin{array}{l}0.004 * \\
*\end{array}$ & Significant \\
\hline 5 & $\begin{array}{l}\text { Experience of Health Problems } \\
\text { during Pre-Natal Period }\end{array}$ & $<--$ & Infant Death & 0.328 & 0.075 & 0.177 & 4.366 & $\begin{array}{l}0.001 * \\
*\end{array}$ & Significant \\
\hline 6 & Utilization of Healthcare & $<--$ & $\begin{array}{l}\text { Experience of Health Problems during } \\
\text { Pre-Natal Period }\end{array}$ & -0.097 & 0.016 & -0.240 & -6.019 & $\begin{array}{l}0.001^{*} \\
*\end{array}$ & Significant \\
\hline 7 & Utilization of Healthcare & $<--$ & Health Problem during Pregnancy & -0.013 & 0.102 & -0.005 & 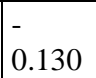 & 0.897 & $\begin{array}{l}\text { Not } \\
\text { Significant }\end{array}$ \\
\hline
\end{tabular}

AMOS Graphic output compiled by Author

** Denotes significant at $1 \%$ level

* Denotes significant at 5\% level 


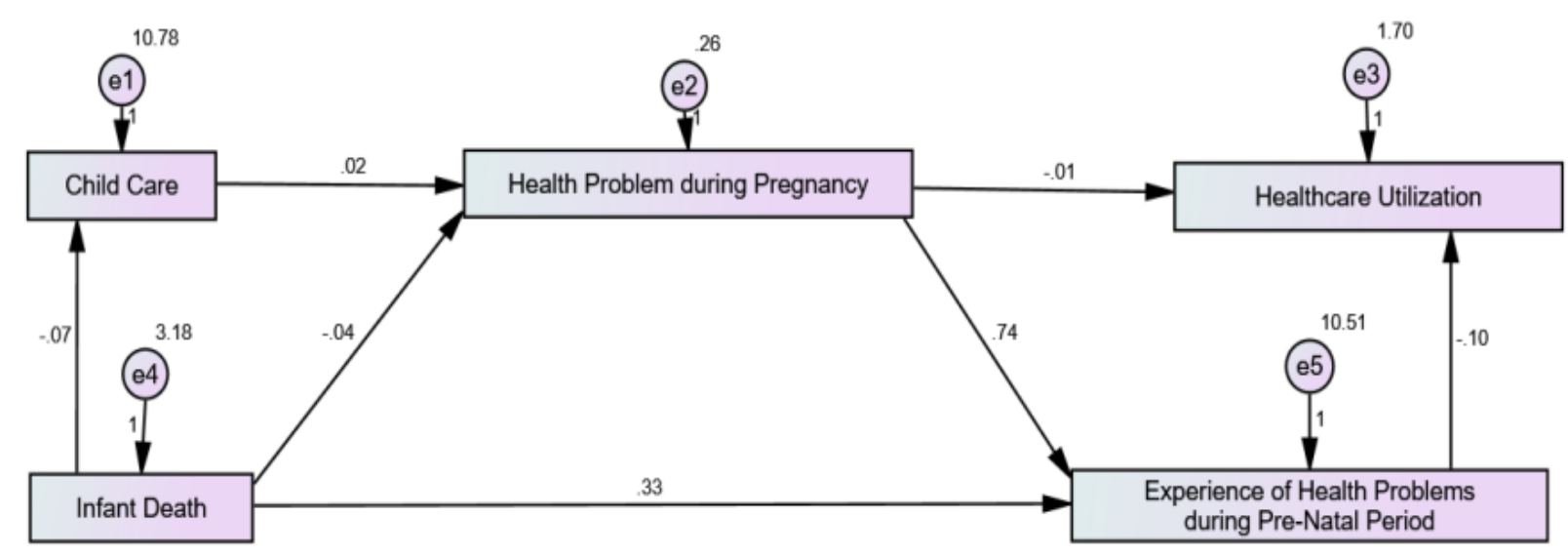

Fig. 7 : Unstandardized model of mediator construct AMOS Graphic Output

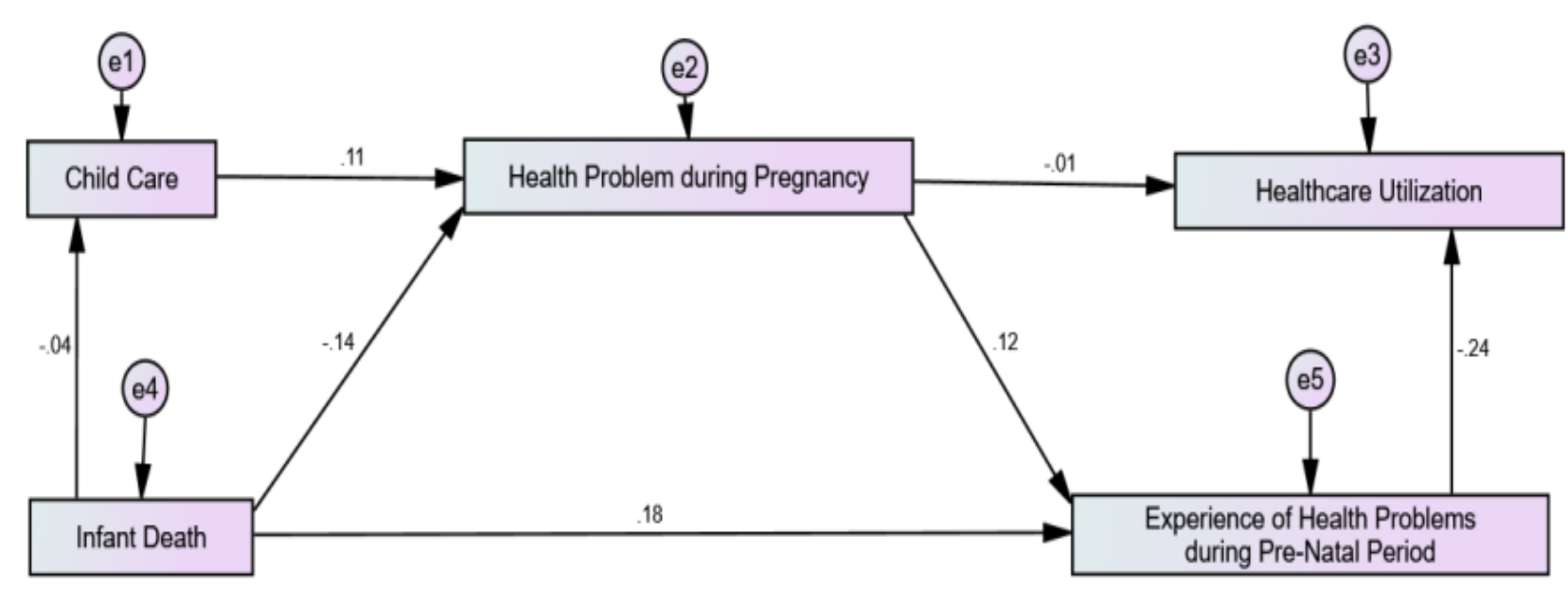

Fig. 8 : Standardized model of mediator construct AMOS Graphic Output

\section{IV.CONCLUSION}

This present study has proven that the factors specifically the experience of health problems during the prenatal period, health problem during pregnancy, child care, infant death and utilization of healthcare are influenced the mother and childcare of Madurai district. The scale used in this study adequately fits into the data gathered in the study area. Further, it concludes that the hypothesized thirteen assumptions models fit the collected sample data. Therefore, the likelihood and statistical association of essential elements estimates, the good fit of the structural model and represents an adequate description of mother and child healthcare indicator support the model fit. In the discriminant validity test, it has been investigated that the correlation of all constructs are below 0.85 . In other words, there are no constructs measuring the same thing. The structural equation model with path analysis has been conducted in the existence of direct and indirect mediator construct; all exogenous constructs show significant direct and indirect effects toward endogenous latent construct through mediator latent construct. In the bootstrap approach, the exogenous constructs except for child care and utilization of healthcare through the mediator construct health problem during pregnancy; and infant death and health problem during 
pregnancy through the mediator child care have partial mediation effects. The above cited mediator constructs have indirect significant contributions or partial mediation toward mother and child healthcare in Madurai district. This finding concludes that the direct and indirect positive effects obtained in the path analysis have been confirmed.

\section{REFERENCES}

[1]. Abosse, Z., Woldie M., Ololo S. (2010): "Factors influencing antenatal care service utilization in Hadiya zone", Ethiop J Health Sci. V.20.

[2]. Aiken, L. S., West, S. G., Woodward, C. K., Reno, R. R., \& Reynolds, K. D. (1994): "Increasing screening mammography in asymptomatic women: Evaluation of a second- generation theory-based program", Health Psychology, 13, 526-538.

[3]. Bollen, K. A. (1987): "Total, direct, and indirect effects in structural equation models", Sociological Methodology, 17, 37-69.

[4]. Bollen, K. A. (1989): "Structural equations with latent variables", New York: Wiley.

[5]. Brown, R. L. (1997): “Assessing specific mediational effects in complex theoretical models", Structural Equation Modeling, 4, 142156.

[6]. Cheung, M. W. L. (2007): "Comparison of approaches to constructing confidence intervals for mediating effects using structural equation models", Structural Equation Modeling, 14, 227246.

[7]. Constantine, M. G. (2007): "Racial microaggressions against African American clients in cross-racial counseling relationships", Journal of Counseling Psychology, 54, 1-16.

[8]. Finlayson, K., \& Downe S. (2013): "Why do women not use antenatal services in low-and middle-income countries? A Meta synthesis of qualitative studies", PLoS Med; 10:e1001373.

[9]. Levant, R. F., Parent, M. C., McCurdy, E. R., \& Bradstreet, T. C. (2015): "Moderated mediation of the relationships between masculinity ideology, outcome expectations, and energy drink use", Health Psychol. 34, 1100-1106. doi: 10.1037/hea0000214.

[10]. MacKinnon, D. P. (2000): "Contrasts in multiple mediator models, Multivariate applications in substance use research: New methods for new questions", In J. Rose, L. Chassin, C. C. Presson, \& S. J. Sherman (Eds.) (pp. 141-160). Mahwah, NJ: Erlbaum.

[11]. Saravanabavan, V, Reejo R.J., Neethidevi, A., and Jayasree, R. (2006): "Travel and Health Care Utilization Pattern of Patients in Vadippati Panchayat Union: A Micro-Level Study using GIS", The Journal of Deccan Geographer, Pune Vol.44 No 2, 2006.

[12]. Saravanabavan, V, (2013): "Patients Perception and Travel Behaviour Pattern in Primary Health Care Center in Haripad Block- A Micro GeoMedical Study", Paper published in the Journal of Language in India, Vol.13:4, April 2013, ISSN 1930 -2940 2013Pp194-207

[13]. Saravanabavan, V., Balaji D., \& Sudharsan R. (2014): "A Geo-Medical Analysis of Chikungunya and Patients Environmental Perception in Madurai City", Journal of JAC Journal of Science, Humanities, and Management,Vol.I No 2 June, pp 111-120,2014, ISSN 2347-9868, 2014.

[14]. Shrout, P. E., Bolger, N. (2002): "Mediation in experimental and non-experimental studies: New procedures and recommendations", Psychological methods. 7(4), 422-445.

[15]. WHO Global Health Observatory (2011): "Antenatal care situations and trends", Women's NCC, Health Cs. Antenatal care.

\section{Cite this article as :}

S. Eswari, V. Saravanabavan, D. Balaji, "Structural Equation Modelling Approach to Determine the Mother and Child Health Care in Madurai District, Tamil Nadu", International Journal of Scientific Research in Science and Technology (IJSRST), Online ISSN : 2395-602X, Print ISSN 2395-6011, Volume 8 Issue 2, pp. 335-344, March-April 2021. Available at

doi : https://doi.org/10.32628/IJSRST218256

Journal URL : https://ijsrst.com/IJSRST218256 